\title{
Development of Rice Porridge with Overripe Tempeh Extract for Infants
}

\author{
Maria Dewi Puspitasari Tirtaningtyas Gunawan Puteri \\ Food Technology \\ Swiss German University \\ Tangerang, Indonesia \\ maria.gunawanputeri@sgu.ac.id \\ Elisabeth Kartika Prabawati \\ Food Technology \\ Swiss German University \\ Tangerang, Indonesia \\ elisabeth.prabawati@sgu.ac.id
}

\author{
Laurensia Christli \\ Food Technology \\ Swiss German University \\ Tangerang, Indonesia \\ laurenchristli@gmail.com \\ Abdullah Muzi Marpaung \\ Food Technology \\ Swiss German University \\ Tangerang, Indonesia \\ abdullah.muzi@sgu.ac.id
}

\begin{abstract}
Children malnutrition in Indonesia, which is mainly caused by inadequate protein intake and poverty, called for low cost high protein source. Formulation of rice porridge, major choice $(39 \%)$ of weaning food type based on initial survey, using overripe tempeh extract as protein source was done to fulfill infant protein requirement with acceptable sensory properties. Chopping increased efficiency of protein extraction by more than 4-fold and therefore extract from chopped overripe tempeh (CORTE) concentrate was selected for formulation. However, the bitter taste of CORTE hindered its usage as single source protein in the rice porridge formula. Formula series were derived from Design Expert software and screening was done based on calculation of energy, nutritional content, and price as formula responses. Screened formula were then further evaluated using hedonic sensory evaluation resulted in the selection of formula using $80 \%$ dry base, $9.30 \%$ isolate soy protein, $10.70 \%$ skim milk, which was cooked in $5 \mathrm{ml}$ CORTE concentrate and $120 \mathrm{ml}$ water. The selected formula was able to meet the national standard requirements, except for dietary fiber, has higher protein digestibility ratio compared to commercial weaning porridge, and was able to fulfill an acceptable portion of protein and indispensable amino acid requirements for infants.
\end{abstract}

Keywords-formulation, malnutrition, overripe tempeh, rice porridge

\section{INTRODUCTION}

Malnutrition is a major health problem in Indonesia. This is mainly caused by inadequate protein intake and poverty [1].

The development and growth of infants is very important. At this period, dietary protein is highly required to assist maintenance and formation of tissue [2], including the formation of enzymes, hormones and antibodies [3]. However, according to The Ministry of Health of the Republic of Indonesia, the protein daily intake of infants is still below the Recommended Dietary Allowance (RDA). There are only $11.5 \%$ infants who succeeded in meeting the RDA [3]. Moreover, the purchasing power of poor families is relatively small, causing limited access to food [4].

Thus, to reduce the number of malnutrition in Indonesia, a low cost, high protein source is needed to fulfill the protein requirement of infants.
Tempeh, a soybean cake fermented by Rhizopus oligosporus [5], is a common traditional Indonesian fermented food that has been consumed for centuries. Since it is a very good source of protein [5], the consumption of tempeh is greater than other protein sources [6].

When fermented $2-5$ days longer than the normal tempeh, it produces overripe tempeh, an over fermented tempeh with pungent odor and grey-brown color that is frequently used in Javanese cuisine [7]. Prolonged fermentation leads to better digestibility due to the increase in the free amino acid [8] and this may be beneficial for infants who have immature digestive system. Moreover, overripe tempeh is known to have umami flavor [8]. Since it is abundant and an inexpensive protein source too, overripe tempeh may be a solution to reduce malnutrition.

Despite its high protein content, overripe tempeh contains high fiber [9]. Too much fiber consumption during infancy is unbeneficial as it may cause satiety before the calorie and nutritional needs can be fulfilled [10]. Thus, there is a need for extracting overripe tempeh to reduce the fiber content.

In consequence, a low cost, ready-to-eat rice porridge with overripe tempeh extract that can fulfill SNI nutritional content with focus on protein content and sensory acceptance was developed.

\section{METHODS}

\section{A. Venue and Time}

The research was done at Life Sciences and Technology Laboratory of Swiss German University, Tangerang from February 2018 to June 2018. Proximate, dietary fiber, amino acid profile and microbial analysis were executed at PT. Saraswanti Indo Genetech (SIG), Bogor.

\section{B. Materials and Equipments}

The required raw materials were tempeh, Setra Ramos rice (Value Plus, Indonesia), garlic powder (Koepoe Koepoe, Indonesia), palm sugar (Haan, Indonesia), oil (Sunco, Indonesia), salt (Refina, Indonesia), isolated soy protein (Shandong Crown Soya Protein, China) and skim milk powder (NZMP, New Zealand). The tempeh was acquired from a tempeh merchant, which located in Sinpasa market, Tangerang Selatan. The tempeh was in a fresh condition, 
wrapped in banana leaves, and the soybeans had been fermented for 3 days.

All chemicals were analytical grade and provided from Merck, Germany, unless stated: bovine serum albumin and pepsin enzyme (Sigma Aldrich, USA) and distilled water (Amidis, Indonesia).

The required equipment was table balance (Tanita, Japan), pocket refractometer (Atago, Japan), oven (WiseVen, Memmert, Germany), filter discs grade 1288 (Sartorius Stedim, Germany), rotary evaporator (Büchi, Switzerland), centrifuge Rotina 35R (Hettlich, Germany and PrO-Research, UK), moisture analyser (Sartorius, Germany), and T60 UV/Vis spectrophotometer (Oasis Scientific, USA).

\section{Preliminary Research}

It was conducted in order to know the preference of weaning food of targeted society, including the consumption habit by giving questionnaires to mothers who live near Posyandu Seruni IX, Desa Pagedangan, BSD, Tangerang Selatan. This community represented middle low income society that lives in urban area.

\section{Overripe Tempeh Extraction}

There were three different extracts: unchopped overripe tempeh extract (UORTE), chopped overripe tempeh extract (CORTE) and overripe tempeh powder extract (ORTPE).

Prior to extraction, overripe tempeh was chopped into small cubes for CORTE, while for ORTPE, overripe tempeh was thinly sliced, oven dried at $60^{\circ} \mathrm{C}$ [7] for 6 hours and milled.

For UORTE and CORTE, overripe tempeh was homogenized with distilled water with the ratio of $1: 4$, then it was heated at $100^{\circ} \mathrm{C}$ for 10 minutes. Afterwards, the sample was cloth-filtered and stirred (cooled down) for 50 minutes. ORTPE was treated similarly but the ratio was 1:9.

\section{E. Dietary Fiber Reduction of Overripe Tempeh Extract}

Dietary fiber was reduced by using vacuum filtration and centrifugation. In vacuum filtration, a Büchner funnel that was covered by a filter disc, was connected to a vacuum pump. The extract was poured through the funnel. Centrifugation was done at $4000 \mathrm{rpm}, 4^{\circ} \mathrm{C}$ for 30 minutes. The supernatant was taken.

The total solid of both methods were determined by heating crucibles with samples at $105^{\circ} \mathrm{C}$ for 4 hours and cooling down in desiccator for 10 minutes until the weight were stable.

\section{F. Formulation and Sensory Analysis}

Formulation of rice porridge consists of rice porridge base formula, water and overripe tempeh extract amount. The rice porridge base formulas were designed by Design Expert 11 software. All of the ingredients underwent focus group discussion (FGD) with 7 trained panelists and 9-scale hedonic sensory test. The hedonic sensory test was examined statistically by using Wilcoxon Test.

Cooking was done by using sealed retort pouch in a pressure cooker for 12 minutes.

\section{G. Rice Porridge Extraction}

Rice porridge was freeze dried at $-40^{\circ} \mathrm{C}$ for 24 hours and ground. Then, it was extracted by using distilled water with the ratio 1:5 at room temperature for 6 hours. It was stirred constantly during the extraction process. Afterwards, the extract was centrifuged at $8000 \mathrm{rpm}$ for 15 minutes. The supernatant was taken for analysis.

\section{H. Protein Digestibility Analysis}

It was done by determining the soluble amino acid content of the sample. Both distilled water and phosphate buffer $\mathrm{pH}$ 8.0 with the volume of $250 \mu \mathrm{L}$ each, were put into $250 \mu \mathrm{L}$ rice porridge extract. Then, it was incubated at $37^{\circ} \mathrm{C}$ for 5 minutes. The reaction was stopped by adding $750 \mu \mathrm{L} \mathrm{10 \%} \mathrm{TCA.} \mathrm{This}$ was treated as the control. For the protein digestibility test, the steps were repeated but the distilled water was substituted with $250 \mu \mathrm{L} 4 \mathrm{mg} / \mathrm{ml}$ pancreatin enzyme solution. Both of the control and the solution with enzyme were centrifuged at $10,000 \mathrm{rpm}$ for 10 minutes. Afterwards, $300 \mu \mathrm{L}$ supernatant was taken and combined with $0.5 \mathrm{M} \mathrm{Na} \mathrm{CO}_{3}$ solution $(1000$ $\mu \mathrm{L})$ and Folin-Ciocalteu reagent $(200 \mu \mathrm{L}, 1: 2)$. Then, UV-V is Spectrophotometer was used to read the absorbance of the samples at the wavelength of $578 \mathrm{~nm}$. By using similar steps, tyrosine standard curve was also made by substituting the sample with various concentration of tyrosine solution. By interpolating to the curve, total soluble amino acid was determined. The protein digestibility was calculated as below:

(AA content enzyme treated - AA content enzyme untreated) / average protein content

\section{DIAAS Calculation [11]}

Digestible indispensable amino acid score, or DIAAS, is another method of measuring protein quality which refers to the capability of indispensable amino acids in meeting the needs of humans.

To determine the DIAAS for a food, there are two data that were required: the digestible indispensable amino acid (DIAA) content per gram of protein in food and the IAA reference ratio. Both were computed as below:

DIAA $=\mathrm{mg}$ of IAA per gram protein of food $\times$ true ileal digestibility coefficient for the same dietary indispensable amino acid*(2)

*The true ileal digestible amino acid was obtained from mg AA per gram of food as consumed basis, per gram of food dry matter, or per gram of protein of food

IAA Reference Ratio = DIAA content in 1 gram protein of food $(\mathrm{mg}) / \mathrm{mg}$ of the same DIAA in 1 gram of reference protein (3)

The DIAAS was calculated as the following:

DIAAS $(\%)=100 \times$ lowest value of digestible IAA reference ratio for a given AA scoring pattern (4)

\section{RESULTS AND DISCUSSION}

\section{A. Preliminary Research}

Respondents were asked to list 5 types of food that were regularly given to their children. The types of food are varying, for instance, steamed rice (nasi tim), commercial weaning porridge, vegetable and fruits, mung bean porridge, etc. However, based on the responses (Figure 1), most of the respondents $(39 \%)$ chose to give their children rice porridge as the first choice (major) weaning food, followed by steamed 
rice (nasi tim) and commercial weaning porridge (21\%). For rice porridge texture (Table 1), most of the respondents $(75 \%)$ preferred not too dense nor too runny texture.

\section{B. Comparison and Selection of Overripe Tempeh Extract}

Initially, all of the extracts were compared based on the protein content. According to Table 2, ORTPE has the most protein content which was slightly different to CORTE. Meanwhile, UORTE has the least protein content and the amount is quite far compared to the other extracts. This is due to size; with smaller size, it is easier for the compound to diffuse through, resulting in faster reaction rate and higher amount of extractable compounds [12]. Thus, only CORTE and ORTPE were being further compared.

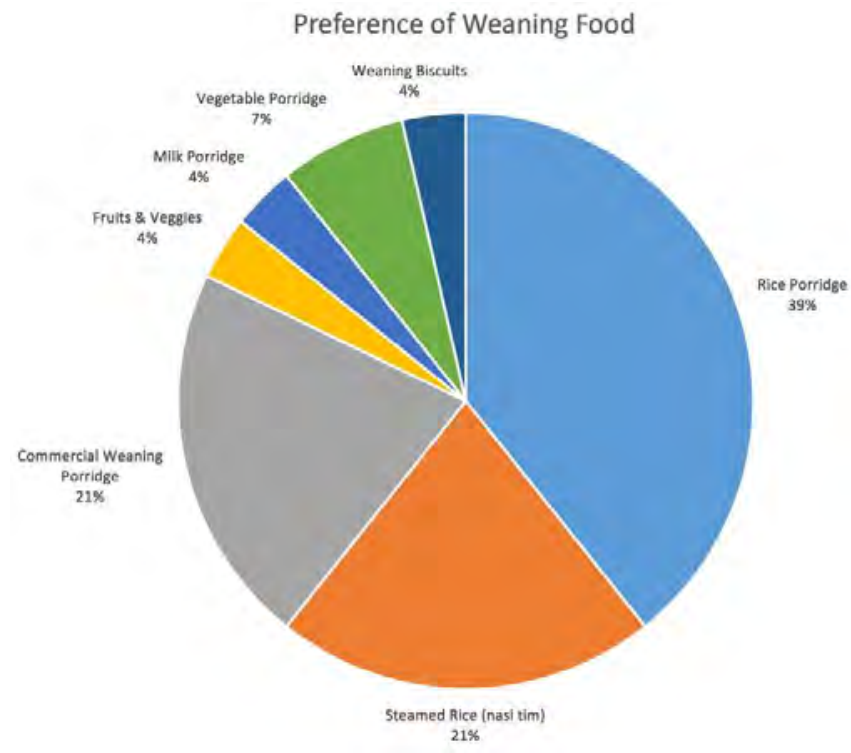

Figure 1. Preference of weaning food

Table 1. Rice porridge texture preference

\begin{tabular}{ccccc}
\hline \multicolumn{5}{c}{ Rice Porridge Texture } \\
\hline \hline & Dense & Not too dense nor too runny & Runny & \\
$\begin{array}{c}\text { Number of } \\
\text { respondents }\end{array}$ & 2 & 21 & 5 & 28 \\
\hline
\end{tabular}

Table 2. Protein and dietary fiber content of overripe tempeh extracts

\begin{tabular}{ccc}
\hline Parameter & $\begin{array}{c}\text { Protein } \\
(\mathbf{g} / \mathbf{1 0 0} \mathbf{g} \text { ORT })\end{array}$ & $\begin{array}{c}\text { Dietary Fiber } \\
(\mathbf{g} / \mathbf{1 0 0} \mathbf{g} \text { ORT })\end{array}$ \\
\hline UORTE & 0.95 & 4.06 \\
CORTE & 4.13 & 10.08 \\
ORTPE & 4.61 & 8.36 \\
\hline
\end{tabular}

Based on Table 3, even though CORTE has slightly lower protein content, slightly higher dietary fiber content and lower yield, it contains more total and indispensable amino acids, it required 7 times less production time and less processing steps compared to ORTPE. Thus, CORTE was chosen.
Table 3. Comparison of CORTE and ORTPE

\begin{tabular}{lrr}
\hline Criteria of Evaluation & CORTE & ORTPE \\
\hline \hline $\begin{array}{l}\text { Protein Content } \\
\text { g/ 100 g ORT) }\end{array}$ & 4.13 & $* 4.61$ \\
$\begin{array}{l}\text { Dietary Fiber Content } \\
\text { (g/ 100 g ORT) }\end{array}$ & 10.08 & $* 8.36$ \\
$\begin{array}{l}\text { Total Amino Acids } \\
\text { (mg/ 100 g ORT) }\end{array}$ & $* 3110.11$ & 2965.38 \\
$\begin{array}{l}\text { Total Indispensable Amino Acids } \\
(\mathrm{mg} / \text { 100 g ORT) }\end{array}$ & $* 1193.02$ & 1065.46 \\
$\begin{array}{l}\text { Production Time (hours) } \\
\text { Yield (\%) }\end{array}$ & $* 1$ & 718.8 \\
Process & 4.23 & $\begin{array}{r}\text { Oven drying, } \\
\text { milling, extraction }\end{array}$ \\
\hline & & $*$ pxreferred result
\end{tabular}

\section{Dietary Fiber Reduction of CORTE}

Too much dietary fiber consumption during infancy is unbeneficial. High consumption of dietary fiber may lead to unfulfilled calorie and nutritional needs since dietary fiber leads to satiety [10].

According to Table 4, centrifugation reduced more total solid compared to vacuum filtration. However, it is inefficient for large scale production due to the small capacity. Despite its less total solid reduction, vacuum filtration provides larger capacity. Thus, vacuum filtration was chosen as the method to reduce the dietary fiber of CORTE.

Table 4. Comparison of dietary fiber reduction method

\begin{tabular}{cccc}
\hline No. & Methods & $\begin{array}{c}\text { Total Solid } \\
(\mathbf{g} / \mathbf{m l})\end{array}$ & $\begin{array}{c}\text { Capacity } \\
(\mathbf{m l} / \mathbf{m i n})\end{array}$ \\
\hline \hline 1. & Cloth-filtered (control) & 0.013 & Unlimited \\
2. & $\begin{array}{c}\text { Cloth-filtered + vacuum } \\
\text { filtration }\end{array}$ & 0.011 & 600 \\
3. & Cloth-filtered + centrifugation & 0.009 & 9 \\
\hline
\end{tabular}

\section{Formulation}

The water amount in the rice porridge is important as it is related to the final texture of the porridge. Trials were done by using several amount of water. It was found that 125 and 150 $\mathrm{ml}$ water produced not too dense nor too runny texture as it was desired by respondents. FGD agreed to use $125 \mathrm{ml}$ of water as the viscosity was more appropriate for infants. Subsequently, the chosen water amount will be further adjusted to the CORTE amount that was going to be added.

Assuming that $100 \%$ base mix (a mixture of $20 \mathrm{~g}$ rice, $4 \mathrm{~g}$ garlic oil, $3 \mathrm{~g}$ palm sugar, $2 \mathrm{~g}$ garlic powder, and $0.18 \mathrm{~g}$ salt) was used, in order to reach the minimum SNI protein standard ( $2 \mathrm{~g} / 100 \mathrm{kcal}), 400 \mathrm{ml}$ of CORTE was needed. However, it was impossible to put in a retort pouch. Consequently, CORTE was concentrated 16 times by using rotary evaporator, resulting in $25 \mathrm{ml}$ of CORTE concentrate. Nevertheless, the taste was very bitter.

Trials were also done in order to determine at which levels the CORTE concentrate got bitter. FGD agreed to use only 5 $\mathrm{ml}$ CORTE concentrate as the taste was not bitter at all and the umami taste can yet still be perceived. From this, it can be concluded also that too much CORTE concentrate will lead to bitter rice porridge. Thus, CORTE was not recommended to be used as a single protein source. 
For that reason, besides base mix, isolated soy protein (ISP) and skimmed milk powder (SMP) were added as other protein sources due to the availability and inexpensive price. Moreover, both have the capability in improving sensory properties, in particular, the appearance, flavor and mouthfeel [13].

It was estimated that base mix, ISP and SMP contains 4.4 $\mathrm{kcal} / \mathrm{g}, 3.6 \mathrm{kcal} / \mathrm{g}$ and $3.65 \mathrm{kcal} / \mathrm{g}$ of energy. The suitable percentages of base mix, ISP and SMP were calculated in order to reach minimum protein content $2.1 \mathrm{~g} / 100 \mathrm{kcal}$ and maximum $3 \mathrm{~g} / 100 \mathrm{kcal}$ with the serving size of 30 grams. Actually, the SNI protein standard for ready-to-eat weaning food is $2-5.5 \mathrm{~g} / 100 \mathrm{kcal}$, but the protein content of the rice porridge base was set to maximum $3 \mathrm{~g} / 100 \mathrm{kcal}$ as ingredients like rice may have a little protein content that may contribute to the final protein content. Moreover, in the end, CORTE concentrate was added to the formulation which also may increase the final protein content. The most suitable percentages were $73-80 \%$ of base mix, $4-11 \%$ of ISP and $9-16 \%$ SMP, as shown in Table 5.

Table 5. Mixture components of rice porridge base in Design Expert

\begin{tabular}{cccccc}
\hline $\begin{array}{c}\text { Compo- } \\
\text { nent }\end{array}$ & Name & Units & Type & Min & Max \\
\hline \hline A & Base Mix & $\%$ & Mixture & 73 & 80 \\
B & ISP & $\%$ & Mixture & 4 & 11 \\
C & SMP & $\%$ & Mixture & 9 & 16 \\
& & & & Total & 100.00 \\
\hline
\end{tabular}

In the Design Expert software, 7 responses were chosen as parameters in choosing the right formulas: energy, protein, fat, carbohydrate dietary fiber and ash content, and price. The software gave 12 runs as a result. Meanwhile, for the responses, all of them were manually calculated and input. The result and responses are shown in Table 6.

Afterwards, all of the parameters were set numerically in the design optimization. The energy, protein, fat, carbohydrate, dietary fiber and ash content were set in range according to SNI standard (Table 7). Meanwhile, the price was set as low as possible (minimized). However, Design Expert did not give any solutions as the dietary fiber content in all of the results exceeded the standard. The only source of the dietary fiber was from the rice itself and it could not be eliminated from the formulation as rice is the main ingredient of the rice porridge. Thus, the dietary fiber was set as none or was not included as a parameter in order to have optimized numerical solutions from Design Expert.

Design Expert gave 22 possible solutions in total with the desirability of $100 \%$. The possible solutions can be seen in Table 8 . All of the possible solutions differed very slightly to each other. Thus, only 3 solutions were taken: Formula 4, 18 and 1 . The decision was made by taking the least protein content, the maximum protein content $(3 \mathrm{~g} / 100 \mathrm{kcal})$ and the middle point in between. All of the 3 formulas were discussed further in the focus group discussion.
Table 6. Result and responses of rice porridge base formulation

\begin{tabular}{|c|c|c|c|c|c|c|c|c|c|}
\hline $\begin{array}{c}\text { A: } \\
\text { Base } \\
\text { Mix } \\
(\%)\end{array}$ & $\begin{array}{l}\text { B: } \\
\text { ISP } \\
(\%)\end{array}$ & $\begin{array}{l}\text { C: } \\
\text { SMP } \\
(\%)\end{array}$ & $\begin{array}{l}\text { Energy } \\
\text { (kcal/g) }\end{array}$ & $\begin{array}{c}\text { Protein } \\
\text { Content } \\
\text { (g/ 100 } \\
\text { kcal) }\end{array}$ & $\begin{array}{c}\text { Fat } \\
\text { Content } \\
\text { (g/ 100 } \\
\text { kcal) }\end{array}$ & $\begin{array}{c}\text { Carbo- } \\
\text { hydrate } \\
\text { (g/ 100 } \\
\text { kcal) }\end{array}$ & $\begin{array}{c}\text { Dietary } \\
\text { Fiber } \\
\text { (g/ 100 } \\
\text { kcal) }\end{array}$ & $\begin{array}{c}\text { Ash } \\
\text { Content } \\
(\mathrm{g} / \\
\mathbf{1 0 0 g})\end{array}$ & $\begin{array}{l}{ }^{*} \text { Price } \\
\text { (IDR) }\end{array}$ \\
\hline 80.000 & 11.000 & 9.000 & 4.24 & 3.03 & 2.58 & 1.88 & 2.14 & 1.31 & 869 \\
\hline 80.000 & 4.000 & 16.000 & 4.25 & 2.09 & 2.58 & 1.88 & 2.14 & 1.48 & 871 \\
\hline 78.769 & 9.922 & 11.309 & 4.24 & 2.99 & 2.55 & 1.88 & 2.12 & 1.43 & 887 \\
\hline 79.942 & 7.516 & 12.543 & 4.25 & 2.57 & 2.58 & 1.88 & 2.14 & 1.40 & 871 \\
\hline 78.776 & 6.378 & 14.847 & 4.24 & 2.51 & 2.55 & 1.88 & 2.12 & 1.52 & 888 \\
\hline 76.484 & 11.000 & 12.516 & 4.22 & 3.33 & 2.49 & 1.88 & 2.06 & 1.58 & 920 \\
\hline 74.755 & 11.000 & 14.245 & 4.21 & 3.47 & 2.44 & 1.88 & 2.02 & 1.72 & 945 \\
\hline 74.722 & 9.278 & 16.000 & 4.21 & 3.24 & 2.44 & 1.88 & 2.02 & 1.77 & 946 \\
\hline 77.632 & 8.709 & 13.660 & 4.23 & 2.92 & 2.52 & 1.88 & 2.09 & 1.55 & 904 \\
\hline 79.942 & 7.516 & 12.543 & 4.25 & 2.57 & 2.58 & 1.88 & 2.14 & 1.40 & 871 \\
\hline 76.496 & 7.504 & 16.000 & 4.22 & 2.85 & 2.48 & 1.88 & 2.06 & 1.67 & 921 \\
\hline 73.000 & 11.000 & 16.000 & 4.19 & 3.62 & 2.39 & 1.88 & 1.98 & 1.86 & 971 \\
\hline
\end{tabular}

*Price was based on $30 \mathrm{~g}$ serving size.

Table 7. The National Standard of Indonesia for Ready-ToEat Weaning Food (SNI 01-7111.4-2005 MP-ASI: Siap Santap)

\begin{tabular}{cccc}
\hline No. & Criteria & Unit & Requirement \\
\hline \hline 1. & Energy & $\mathrm{kcal} / \mathrm{g}$ & $\geq 0.8$ \\
2. & Ash Content & $\mathrm{g} / 100 \mathrm{~g}$ & $<3.5$ \\
3. & Protein & $\mathrm{g} / 100 \mathrm{kcal}$ & $2-5.5$ \\
4. & Fat & $\mathrm{g} / 100 \mathrm{kcal}$ & $1.5-4.5$ \\
5. & Carbohydrate & $\mathrm{g} / 100 \mathrm{kcal}$ & $<7.5$ \\
6. & Dietary Fiber & $\mathrm{g} / 100 \mathrm{kcal}$ & $<1.25$ \\
\hline
\end{tabular}

Table 8. Rice porridge base formula optimization results

\begin{tabular}{|c|c|c|c|c|c|c|c|c|c|}
\hline No. & $\begin{array}{c}\text { A: } \\
\text { Base } \\
\text { Mix } \\
\%\end{array}$ & $\begin{array}{l}\text { B: } \\
\text { ISP } \\
\%\end{array}$ & $\begin{array}{c}\text { C: } \\
\text { SMP } \\
\%\end{array}$ & $\begin{array}{c}\text { Energy } \\
\text { kcal/g }\end{array}$ & $\begin{array}{c}\text { Protein } \\
\text { Content } \\
\text { g/100 } \\
\text { kcal }\end{array}$ & $\begin{array}{c}\text { Fat } \\
\text { Content } \\
\text { g/100 } \\
\text { kcal }\end{array}$ & $\begin{array}{l}\text { Carbohydrate } \\
\text { Content g/ } \\
100 \text { kcal }\end{array}$ & $\begin{array}{c}\text { Ash } \\
\text { Content } \\
\text { g/100g }\end{array}$ & $\begin{array}{c}\text { *Price } \\
\text { IDR }\end{array}$ \\
\hline 4 & 80.000 & 7.504 & 12.496 & 4.25 & 2.56 & 2.58 & 1.88 & 1.40 & 870 \\
\hline 15 & 80.000 & 7.609 & 12.391 & 4.25 & 2.58 & 2.58 & 1.88 & 1.39 & 870 \\
\hline 16 & 80.000 & 7.756 & 12.244 & 4.25 & 2.60 & 2.58 & 1.88 & 1.39 & 870 \\
\hline 19 & 80.000 & 7.872 & 12.128 & 4.25 & 2.61 & 2.58 & 1.88 & 1.39 & 870 \\
\hline 12 & 80.000 & 7.997 & 12.003 & 4.25 & 2.63 & 2.58 & 1.88 & 1.38 & 870 \\
\hline 2 & 80.000 & 8.128 & 11.872 & 4.25 & 2.65 & 2.58 & 1.88 & 1.38 & 870 \\
\hline 22 & 80.000 & 8.246 & 11.754 & 4.25 & 2.66 & 2.58 & 1.88 & 1.38 & 870 \\
\hline 13 & 80.000 & 8.355 & 11.645 & 4.25 & 2.68 & 2.58 & 1.88 & 1.38 & 870 \\
\hline 6 & 80.000 & 8.522 & 11.478 & 4.25 & 2.70 & 2.58 & 1.88 & 1.37 & 870 \\
\hline 10 & 80.000 & 8.628 & 11.372 & 4.25 & 2.71 & 2.58 & 1.88 & 1.37 & 870 \\
\hline 8 & 80.000 & 8.828 & 11.172 & 4.25 & 2.74 & 2.58 & 1.88 & 1.36 & 870 \\
\hline 9 & 80.000 & 9.025 & 10.975 & 4.25 & 2.77 & 2.58 & 1.88 & 1.36 & 870 \\
\hline 20 & 80.000 & 9.170 & 10.830 & 4.25 & 2.79 & 2.58 & 1.88 & 1.36 & 869 \\
\hline 18 & 80.000 & 9.297 & 10.703 & 4.25 & 2.80 & 2.58 & 1.88 & 1.35 & 869 \\
\hline 11 & 80.000 & 9.484 & 10.516 & 4.25 & 2.83 & 2.58 & 1.88 & 1.35 & 869 \\
\hline 21 & 80.000 & 9.670 & 10.330 & 4.25 & 2.85 & 2.58 & 1.88 & 1.34 & 869 \\
\hline 5 & 80.000 & 9.775 & 10.225 & 4.25 & 2.88 & 2.58 & 1.88 & 1.34 & 869 \\
\hline 7 & 80.000 & 9.988 & 10.012 & 4.25 & 2.90 & 2.58 & 1.88 & 1.34 & 869 \\
\hline 3 & 80.000 & 10.165 & 9.835 & 4.25 & 2.92 & 2.58 & 1.88 & 1.33 & 869 \\
\hline 17 & 80.000 & 10.629 & 9.371 & 4.25 & 2.98 & 2.58 & 1.88 & 1.32 & 869 \\
\hline 14 & 79.998 & 10.821 & 9.181 & 4.25 & 3.01 & 2.58 & 1.88 & 1.31 & 869 \\
\hline 1 & 80.000 & 11.000 & 9.000 & 4.25 & 3.03 & 2.58 & 1.88 & 1.31 & 869 \\
\hline
\end{tabular}

*Price was based on $30 \mathrm{~g}$ serving size.

The sensory attributes of the three formulas were described in the focus group discussion (Table 9). FGD agreed to use Formula 4 and Formula 18 as samples for hedonic sensory test since the mouthfeel of Formula 1 was too sticky and too thick. 
Table 9. Sensory descriptions of rice porridge base formulations by trained panelists

\begin{tabular}{cl}
\hline Formulas & \multicolumn{1}{c}{ Descriptions } \\
\hline \hline \multirow{3}{*}{ Formula 4 } & $\begin{array}{l}\text { The color was a little bit brown. The aroma was } \\
\text { sweet, milky and dominated by garlic. It tasted } \\
\text { sweet, salty and a little bit savory. Overall, the taste } \\
\text { was light and balanced. The texture was soft, while } \\
\text { the mouthfeel was thick. }\end{array}$ \\
& $\begin{array}{l}\text { The taste was balanced and the aroma was savory } \\
\text { and dominated by garlic. The color and texture were } \\
\text { similar to the previous formula; however, the } \\
\text { Formula 18 } \\
\text { mouthfeel was thinner. }\end{array}$ \\
& $\begin{array}{l}\text { The color was similar to other formulas. Despite its } \\
\text { sweet taste and garlic aroma, the mouthfeel was } \\
\text { andesirable. It was too sticky and too thick (thicker } \\
\text { than Formula 4). Moreover, it had sour aftertaste. }\end{array}$ \\
\hline &
\end{tabular}

\section{E. Hedonic Sensory Test}

From the previous results, Formula 4 and Formula 18 with $5 \mathrm{ml}$ CORTE concentrate and $120 \mathrm{ml}$ water were chosen. Both resulting porridges were evaluated by 30 mothers in Desa Pagedangan, BSD, Tangerang Selatan. Formula 4 and 18 were labelled as Porridge A and B, respectively. Both of the samples were evaluated based on the overall acceptance, taste, aroma, appearance and texture. It can be seen from the results (Table 10), all of the sensory attributes were not significantly different $(\mathrm{P}-$ Value $>0.05)$ except for the taste. The taste between the two formulations were significantly different as the P-Value was lower than 0.05 . Based on all of the sensory attributes, nearly all of them had the mean value above 6 , which means that it was slightly liked.

Table 10. Hedonic sensory test results

\begin{tabular}{ccccc}
\hline Sensory Attributes & Porridge A & Porridge B & P-Value \\
\hline \hline Overall Acceptance & $6.70 \pm 0.84$ & $6.47 \pm 0.73$ & 0.052 \\
Taste & $6.73 \pm 0.87$ & $6.40 \pm 0.93$ & 0.014 \\
Aroma & $5.93 \pm 1.11$ & $6.03 \pm 1.43$ & 0.669 \\
Appearance & $6.67 \pm 1.06$ & $6.53 \pm 1.20$ & 0.234 \\
Texture & $6.80 \pm 0.55$ & $6.83 \pm 0.70$ & 0.655 \\
\hline
\end{tabular}

\section{F. Selection of Final Product}

As Porridge A and Porridge B were overall not significantly different, the selection for the final product was based on the protein content and the cost. Porridge B, which used Formula 18 as the porridge base, had a slightly higher protein content $(2.80 \mathrm{~g} / 100 \mathrm{kcal})$ and a slightly lower cost (IDR 869) than Formula 4, which can be seen in Table 8. As a consequence, Porridge B, which consisted of Formula 18 porridge base, $5 \mathrm{ml}$ CORTE concentrate and $120 \mathrm{ml}$ water, was chosen as the final product.

\section{G. Protein Adequacy Estimation}

Infants are recommended to be introduced to textured weaning porridge, like rice porridge with overripe tempeh extract, starting from the age of 9 months old and by 12 months old, family food is introduced [14]. According to Peraturan Menteri Kesehatan Republik Indonesia Nomor 75 Tahun 2013, the RDI of protein for 7 - 11 months old Indonesian children per day is 18 grams. The protein content estimation of a portion of rice porridge is 4.5 grams (Table 10). Thus, one serving can fulfil only $4.5 / 18$ RDI.
Nevertheless, The Ministry of Health of the Republic of Indonesia suggested that $9-12$ months old infants have to consume $3 \mathrm{x}$ weaning food, $2 \mathrm{x}$ snacks (fruits) and $2 \mathrm{x}$ breastmilk in a day. Infants with that age range should be given minimum $200 \mathrm{ml}$ of breastmilk per consumption as normally $400-600 \mathrm{ml}$ of breastmilk is given in a day [15]. Assuming that $3 \mathrm{x}$ weaning food and $2 \mathrm{x} 200 \mathrm{ml}$ breastmilk are consumed, then it can fulfil $17.6 / 18$ protein RDI which is adequate for infants (Table 11).

\section{H. Indispensable Amino Acid Adequacy Estimation}

The DIAAS score of rice porridge was estimated based on ingredients that contain protein: ISP, SMP and CORTE concentrate. The score of rice porridge for both 6 months and $1-2$ years old infants were 57 and $61 \%$, respectively. This means that by consuming only rice porridge, it can only fulfill $57 \%$ and $61 \%$ of the requirements. From Table 12, it can be seen that breastmilk had score exceeded $100 \%$, which refers to high protein quality. Thus, if rice porridge was consumed together with breastmilk in a day, then the indispensable amino acid requirements can be fulfilled.

Table 11. Protein content calculation of weaning food and breastmilk consumption

\begin{tabular}{|c|c|c|c|c|}
\hline No. & Food & $\begin{array}{c}\text { Weight } \\
\text { (g) }\end{array}$ & $\begin{array}{l}\text { Protein } \\
\text { (g/ 100 g) }\end{array}$ & $\begin{array}{l}\text { Protein content in } \\
\text { the mixture (g) }\end{array}$ \\
\hline \multirow[t]{4}{*}{1.} & Porridge B & & & \\
\hline & ISP & 2.8 & 90.0 & 2.5 \\
\hline & SMP & 3.2 & 32.9 & 1.1 \\
\hline & CORTE & 80.0 & 1.2 & 0.9 \\
\hline \multicolumn{4}{|c|}{ TOTAL PROTEIN IN 1 SERVING (g) } & 4.5 \\
\hline \multicolumn{4}{|c|}{ TOTAL PROTEIN IN 3 SERVINGS (g) } & 13.6 \\
\hline 2. & Breastmilk & 200.0 & 1.0 & 2 \\
\hline \multicolumn{4}{|c|}{ TOTAL PROTEIN IN 2 SERVING (g) } & 4 \\
\hline \multicolumn{4}{|c|}{ GRAND TOTAL OF PROTEIN (g) } & 17.6 \\
\hline \multicolumn{5}{|c|}{ Table 12. DIAAS score of rice porridge and breastmilk } \\
\hline \multirow{2}{*}{\multicolumn{3}{|c|}{ Infants Age Group }} & \multicolumn{2}{|c|}{ DIAAS (\%) } \\
\hline & & & Rice Porridge & Breastmilk \\
\hline \multicolumn{3}{|c|}{6 months old } & 57 & 684 \\
\hline \multicolumn{3}{|c|}{$1-2$ years old } & 61 & 760 \\
\hline
\end{tabular}

\section{Protein Digestibility of Rice Porridge}

Protein digestibility of selected rice porridge (Porridge B) was done by determining the soluble amino acid content in the sample. The availability of amino acid is a critical parameter to evaluate protein quality of food [16]. In this assay, commercial weaning porridge (CWP) and rice porridge with overripe tempeh extract (Porridge B) were used as the samples. Both of the samples were examined for the protein content and the soluble amino acid content without and with enzyme. From those data, protein digestibility could be determined as shown in Table 13. The protein digestibility ratio of rice porridge with overripe tempeh extract and commercial weaning porridge were 5.13 and 3.48 in sequence. Due to higher ratio number, rice porridge with overripe tempeh extract was more digestible than the commercial weaning porridge. The availability of overripe tempeh in the rice porridge may increase the protein digestibility as lactic acid bacteria, which works during tempeh fermentation along with mold, produces protease enzyme to 
break down protein into amino acid [17]. Thus, lactic acid bacteria increase the protein digestibility.

Table 13. Soluble amino acid content (protein digestibility) of rice porridge with overripe tempeh extract and commercial weaning porridge

\begin{tabular}{|c|c|c|c|c|}
\hline Sample & $\begin{array}{c}\text { Average } \\
\text { SAA } \\
\text { Content } \\
\text { Without } \\
\text { Enzyme } \\
\text { (mg tyrosine } \\
\text { eq/g dry } \\
\text { base) }\end{array}$ & $\begin{array}{c}\text { Average } \\
\text { SAA Content } \\
\text { with Enzyme } \\
\text { (mg tyrosine } \\
\text { eq/g dry } \\
\text { base) }\end{array}$ & $\begin{array}{c}\text { Average } \\
\text { Protein } \\
\text { Content } \\
\text { (mg BSA } \\
\text { eq/g dry } \\
\text { base) }\end{array}$ & $\begin{array}{c}\text { Protein } \\
\text { Digestibility } \\
\text { (ratio) }\end{array}$ \\
\hline $\begin{array}{l}\text { Porridge } \\
\text { B-1 }\end{array}$ & 17.18 & 71.45 & 10.36 & 5.24 \\
\hline $\begin{array}{l}\text { Porridge } \\
\text { B-2 }\end{array}$ & 13.54 & 70.63 & 11.35 & 5.03 \\
\hline \multicolumn{4}{|c|}{ Average Protein Digestibility of Rice Porridge } & 5.13 \\
\hline CWP-1 & 9.69 & 29.57 & 6.37 & 3.12 \\
\hline CWP-2 & 14.73 & 39.47 & 6.44 & 3.84 \\
\hline \multicolumn{4}{|c|}{$\begin{array}{c}\text { Average Protein Digestibility of Commercial Weaning } \\
\text { Porridge }\end{array}$} & 3.48 \\
\hline
\end{tabular}

\section{CONCLUSION}

Porridge was selected as the application base of overripe tempeh extract for low cost high protein weaning food due to its popularity in middle-low income society. Extract of chopped overripe tempeh was chosen due to its efficiency in terms of protein and dietary fibre content, AA profile, yield, processing steps and production time. The extract concentrate was able to act as protein source in the formula together with isolate soy protein and skim milk powder in the resulting rice porridge. The selected formula was able to meet the national standard requirement of rice porridge, except for dietary fibre. Upon consumption pattern suggested by The Ministry of Health of the Republic of Indonesia and continuation of breastfeeding practice for infants under 1-year-old, the rice porridge formula was able to contribute acceptable protein and indispensable amino acid requirements. The selected formula was also shown to have higher protein digestibility compared to commercial weaning porridge.

\section{ACKNOWLEDGMENT}

This research project was supported by a grant from the Directorate General of Resources for Science, Technology and Higher Education of the Republic of Indonesia with contract number $0789 / \mathrm{K} 4 / \mathrm{KM} / 2018$.

\section{REFERENCES}

[1] O. Muller and M. Krawinkel, "Malnutrition and health in developing countries", Canadian Medical Association Journal, vol. 173, no. 3, pp. 279-286, 2005.

[2] C. Dupont, "Protein requirements during the first year of life", The American Journal of Clinical Nutrition, vol. 77 , no. 6, pp. 1544S1549S, 2003.

[3] Kementerian Kesehatan Republik Indonesia, "Situasi Gizi di Indonesia", Jakarta: Pusat Data dan Informasi Kementerian Kesehatan RI, 2016.

[4] S. Nazara, A. Patunru, M. Tambunan and G.I. Suryanto, "Memperkuat ketahanan pangan dan energi nasional dalam era persaingan global", Jakarta: Ikatan Sarjana Ekonomi Indonesia, 2008

[5] M.T. Murray, J. Pizzorno and L. Pizzorno, "The Encyclopedia of Healing Foods", New York: Atria Books, 2005.

[6] M. Astuti, A. Meliala, F.S. Dalais and M.L. Wahlqvist, "Tempe, a nutritious and healthy food from Indonesia", Asia Pacific Journal of Clinical Nutrition, vol. 9, no. 4, pp. $322-325,2000$.
[7] T.R. Hassanein, E.K. Prabawati and M.D.P.T. Gunawan-Puteri, "Analysis of chemical and microbial changes during storage of overripe tempeh powder as seasoning", International Journal of Science and Engineering, vol. 8, no. 2, pp. 131 - 134, 2015.

[8] H.C. Wijaya and M.D.P.T. Gunawan-Puteri, "Tempe semangit, the overripe tempe with natural umami taste", Umami Indonesia, vol. 3, no. 3 , pp. $1-5,2015$

[9] P.D. Babu, R. Bhakyaraj and R. Vidhyalakshmi, "A low cost nutritious food 'tempeh' - a review", World Journal of Dairy \& Food Sciences vol. 4 , no. 1 , pp. $22-27,2009$.

[10] J. Bhatia, "Perinatal Nutrition: Optimizing Infant Health and Development", Florida: CRC Press, 2004.

[11] FAO, "Dietary protein quality evaluation in human nutrition", Rome: FAO Expert Consultation Report, 2013.

[12] M.A.A. Meireles, "Extracting Bioactive Compounds for Food Products", Florida: CRC Press, 2009.

[13] R. Manohar, G.R.U. Devi, S. Bhattacharya and G.V. Rao, "Wheat porridge with soy protein isolate and skimmed milk powder: rheological, pasting and sensory characteristics", Journal of Food Engineering, vol. 103, no. 1, pp. 1 - 8, 2011

[14] Kementerian Kesehatan Republik Indonesia, "Makanan Sehat untuk Bayi”, Jakarta: Kementerian Kesehatan Republik Indonesia, 2011.

[15] T. Soenardi, "Makanan untuk Tumbuh Kembang Bayi", Jakarta: Gramedia Pustaka Utama, 1996.

[16] W.L. Bryden and X.H. Li, "Amino acid digestibility and poultry feed formulation: expression, limitations and application", Revista Brasileira de Zootecnia, vol. 39, 2010.

[17] E. Bartkiene, V. Krungleviciute, G. Juodeikiene, D. Vidmantiene and Z. Maknickiene, "Solid state fermentation with lactic acid bacteria to improve the nutritional quality of lupin and soya bean", Journal of the Science of Food and Agriculture, vol. 95, no. 6, pp. 1336-1342, 2014 